https://doi.org/10.36240/etf-238.02

\title{
Zentai Mária
}

\section{Túlvilági képek}

\section{(A fantasztikum alakváltása Vörösmarty müveiben az 1830-as években)}

A túlvilági kép címü ballada (Gyulai szerint „beszélyke”) ${ }^{1}$ az 1836-ra kiadott Aurorában jelent meg először. Ma már nem tartozik a közismert vagy sokat elemzett Vörösmarty-versek körébe, de a kritikai kiadás úgy tudja, hogy megjelenésekor rövid idő alatt igen népszerü lett, sokat szavalták nyilvánosan, és maga Vörösmarty is kedves saját versei között tartotta számon; Szerb Antal szerint egyenesen ezt szerette a legjobban. ${ }^{2}$ Az sem lehet véletlen, hogy Arany János Murány ostroma címü müvének mottójául választotta két sorát („O hölgy! az Isten gyönyörül / Teremte tégedet."). A Vörösmarty életében megjelent legalaposabb életmüelemzés, Erdélyi János 1845-ös Irodalmi Örbeli tanulmánya szinte patetikus lelkesedéssel ünnepli $A$ túlvilági képet. Ezen a ponton máris érdemes megállni és elgondolkodni. Erdélyi lelkesedése ugyanis nehezen érthető, nehezen illeszthető kritikai normarendszerébe. A versben egy ifjú hütlen kedvese sírját ássa fel, ám a koporsó menekül előle, egyre mélyebben fúrja magát a földbe. A föld közepében az ifjú megvallja, hogy ö ölte meg a lányt. Az üldözés folytatódik, a föld túlsó oldalán, egy szebb világban a koporsó megnyílik, a lány ártatlanul és gyönyörüen kel ki belőle. Itt eltünik a kép, az ifjú fölébred és maga mellett látja lázas betegségében őt ápoló kedvesét, akiben felismeri és elfogadja a túlvilági kép kissé fakóbb evilági mását („Nem oly derült, nem oly vidám,/ De vonzóbb földi szép"). Hogyan lelkesedhetett ezért a versért a túlzásokat, szélsőségeket mindig elutasító, a tudás és a tapasztalás értékeit nagyrabecsülő, ${ }^{3}$ a romantika horrorisztikus-hatásvadász sajátosságait kárhoztató Erdélyi? Mondhatnánk: biztosan a végső fordulat, a realitás kettős, a narrátor és a hős nézöpontjából egyaránt megerősített győzelme tetszett neki (ti. egyrészt az elbeszélő lázálomnak minősíti a koporsós jelenetet: „Egy lázbetegnek álma volt /Mind, amit szenvedett”, másrészt a hős a „földi szép” szerelmében talál „üdvöt”). Ám épp ellenkezőleg: eleinte úgy tünik, Erdélyi épp az őrületet, a lázálmot magasztalja föl: /az olvasó/ „mohó gyönyörrel kapna e mü után, és felfogná, hogy nincs magasztosabb állapota lelkünknek, mint amit örültség vagy láz alatt kevesen éreznek. Az örültség dicső eszme költőnek, mert ad bölcseségben szólania és lángnyelven, szabadon, úgy a szívhez, mint a fejhez. És az ifjúkor legszebb ábrándjai nem őrültség-e, az önfeláldozás nem őrültség-e?" "Ha itt megszakasztanánk az idézetet, érdekes Erdélyi-rejtélyt konstruálhatnánk. De ha végigolvassuk, igazat fogunk adni a kritikai kiadás szerkesztőinek, Horváth Károlynak és Martinkó Andrásnak, akik

${ }^{1}$ Gyulai 1985. 239-240. (első megjelenése: 1866.)

2 „,...ez a témája annak a költeménynek, melyet Vörösmarty a legjobban szeretett versei közül, A Túlvilági Képnek.” Szerb 1943. 297.

${ }^{3}$ Erdélyi kritikusi-elméleti nézeteiről vö. Korompay H. János 1998. (különösen 229-289.).

${ }^{4}$ Erdélyi 1886. 182. 
szerint Erdélyi politikai allegóriaként értelmezte a verset. Az idézett rész vége: „Nem őrültség-e magyar költészetben »egy új világ, új élet, dicsőbb ég, dicsőbb nap « emlegetése? És van-e szebb, mint az ifju kor ábrándai, mint a föláldozás? és volna-e szebb, mint új élet a magyar világnak?"5 Aki 1845-ben új életet kíván a magyar világnak, az minden valószínüség szerint valóban politikai üzenetet olvas a versben. Hozzátehetjük: ez a késztetés olyan erős, hogy elfedi például azt, hogy a kérdéses versszak („S egy új világot lel vala,/ Körül új életet/ $\mathrm{S}$ dicsőbb eget, dicsőbb napot,/ Az új világ felett.”) igen közeli parafrázisa a bibliai János Jelenései híres helyének, amikor az utolsó ítélet után (amikor a tenger és az alvilág kiadja a halottakat) új ég, új föld tünik föl. Erdélyi, aki pedig maga is szívesen parafrazálja a Biblia szövegét (az idézett részben is akad ilyen, a „lángnyelven szólás”), nem reagál rá.

Erdélyi politikai olvasata ugyanúgy kihúzza a lázálom ${ }^{6}$ borzalmainak méregfogát (mármint azt, hogy a vers első háromnegyed részét komolyan kelljen venni), mintha a realitás diadalát dicsérné, vagyis nem tagadja meg a művészet harmonikus-kiegyenlítő szerepét valló önmagát. Értelmezésének iránya sokatmondó. A mai olvasó számára leginkább abszolút magán-rémtörténetnek látszó balladát kiemeli a magánélet és az egyén szférájából és közösségi, nemzeti dimenziót ad neki (,új magyar világ”). Ezzel még az életmü lezárása elött, már Vörösmarty életében megkezdi az 1830-as évek uralkodó jellegének meghatározását. A korszakoláshoz is ad mintát: noha először berzenkedni látszik amiatt, hogy a vizsgált háromkötetes kiadás beosztása „külső körülményen” alapul (a kötetek kronológiai rendben adják Vörösmarty műveit, a második kötet az 1824-31 közötti versekkel körülbelül a Trattner-Károlyi-féle első kiadás anyagát tartalmazza), azután mégis meggyőzi magát arról, hogy a költő változhat, haladhat, és így mégis rendben levő a tagolás, benne az is, hogy a harmadik kötet (,szakasz”) 1832-vel kezdődik.

Az életmünek az 1830-as évek elején bekövetkező markáns változása a Vörösmarty-szakirodalom legbiztosabb tételeinek egyike. A kortársak még inkább csak az eposzírás abbahagyását érzékelték és ezt kommentálták ízlésük, esztétikai felfogásuk és az általuk képviselt irodalmi program pillanatnyi állapotának és érdekeinek megfelelően (nem véletlenül fogalmazok ilyen tiszteletlenül: Toldy pl. a Vörösmarty munkáiról írott Aesthetikai levelekben 1826-28-ban úgy látta, hogy „,nemzetünknek most virít eposzi lelkesedésü kora”, 1839-ben a Szontágh Gusztávval folytatott vitájában az eposszal szemben a dráma korszerüsége mellett kardoskodott, majd az 1850-es években mindent elkövetett, hogy Arany Jánost eposzírásra vegye rá...). A XX. század a müfajváltásban a költő világfelfogásának változását is érzékeli. Babitstól Martinkó Andrásig, Szerb Antaltól Tóth Dezsőig elméleti alapállástól szinte függetlenül ugyanazokat az elemeket hangsúlyozzák a kutatók: a túláradó képzelet visszaszorítását, megfékezését, az álmokkal szemben a való, a

${ }^{5}$ Erdélyi 1886.

${ }^{6}$ Itt jegyzem meg, hogy az ifjú álmának orvosi szempontú elemzését írta meg a század elején Lauschmann Gyula 1901-ben. Lauschmann szerint a „hasi hagymáz”, vagyis a hastífusz jellegzetes delíriumát írja le a költő.

${ }^{7}$ Erdélyi 1886. 164-165. 
múlt helyett a jelen és a jövő elötérbe kerülését, kilépést az egyéni szférából a nemzetüdv, az emberüdv keresése felé, a „földi menny” új színterét: a közösség, a nemzet érdekében való munkálkodást, a férfimunka és férfidicsőség alapvetően bizakodó világát. Ez utóbbi mondatban Martinkó András tanulmányának a terminológiáját használtam, aki tudtommal utoljára vállalkozott arra, hogy egyetlen nagy metaforában, föld és ég dichotómiájában foglalja össze Vörösmarty költészetének meghatározó vonásait. ${ }^{8}$ Eszerint a Csongor és Tünde megírása után „az egész Vörösmarty-költészet jobban kilép az egyéni szférából. Nem föltétlenül úgy kell ezt érteni, hogy messzibb ható kozmikus távlatok nyílnak meg - eddigi költészetének e téren nem volt szüksége túlhaladásra -, hanem úgy, hogy a »földi menny« ideája extrovertálódik, színtere fokozatosan nem az én, hanem a közösség: a nemzet és $a z$ ember, tartalma pedig nem az egyéni boldogság, hanem a nemzet üdve, illetve az emberüdv." "9 Martinkó majd az 1840-es évek közepén lát újabb változást: a költő emberképét egyre erősebben befolyásoló szkepszist, a sárprincípium legyőzhetetlenségének felismerését a Gondolatok a könyvtárban és Az emberek megírásától kezdve.

Ebből a rövid összefoglalóból is látszik, hogy az eposzok és a Csongor és Tünde utáni Vörösmartyt lírikusként tartjuk számon, hiszen a változás jellemzése nyilvánvalóan a Szózatot és a hozzá hasonló, valóban a nemzetsors-nemzetüdv tematikus körében mozgó költeményeket rajzolja ki és helyezi a figyelem középpontjába (Martinkóéhoz hasonló megfogalmazást más Vörösmarty-kutatóktól is idézhetnénk). Az évtized egyéb mủvei árnyékba kerülnek, talán az egy Szép Ilonka kivételével, amelynek remekmü-volta kiharcolja magának a figyelmet, noha jellegében egy világ választja el a Szózattól.

Elgondolkodtató ugyanakkor, hogy az életmü müfajkínálata éppen az 1830-as években a leggazdagabb, legváltozatosabb. Eposzt ugyan valóban nem ír már Vörösmarty, de lírai verseken kívül ír ebben az évtizedben elbeszélő költeményt és balladát, tragédiát és vígjátékot (az egyetlent), novellát (a hatból ötöt) és kritikát, dramaturgiai értekezést és vitacikket - hogy az akadémiai munkáit most ne is említsük.

Elgondolkodtató az is, hogy az eposzok mitikus képzeletvilága valóban a múlté, de hat novellájából négyet Turóczi-Trostler mesenovellaként elemez, hogy „kísértetes" vagy annak látszó ${ }^{10}$ balladái kivétel nélkül ebben az évtizedben íródnak, vagyis - mint azt több kutató is megjegyzi - a fantasztikum vonzóereje nem csökken, csak alakot vált (ezeket az új alakokat viszont alacsonyabbra értékelik).

A következőkben a fantasztikum alakváltásának körébe sorolható művek közül szeretnék néhányról beszélni. A túlvilági kép (1835) és a Csiga Márton viszontag-

${ }^{8}$ Martinkó 1977.

${ }^{9}$ Uo. 211.

${ }^{10}$ Igazi kísértetes balladát Vörösmarty tulajdonképpen nem sokat írt: Az éjféli ház és a Csák magyar nyelvű változata sorolható ide. A túlvilági képben kiderül, hogy álom az, ami természetfelettinek látszott, $A z$ özvegyben a „sírok közül” érkezőről kiderül, hogy túlélte a mérgezést, $A$ hü lovag „,rémi arcúlattal” éjfelenként a romokon kóborló hősét pedig, noha „Sem élet- sem halálban / Nem lel vigasztalást", a vers szövege végül is nem kíséri tényleges haláláig. 
ságai (1837 eleje) különösen érdekelt, mivel mindkettőre jellemző a hirtelen váltás fantasztikum és realitás között: kiderül, de csak a mü legvégén, hogy a leírt cselekménysort a hős álmodta, és a különös álmok okára racionális magyarázatot ad az elbeszélő (láz, illetve túlterhelt gyomor). Nem foglalkozom A Rommal, mivel ott az elbeszélő elöre közli, hogy az ifjú kalandor álmait fogja leírni, illetve $A$ holdvilágos éjjel, amelyben viszont a felébredés után azt a „racionális” magyarázatot kapjuk, hogy a keresztútnál kísértő kárhozott szellem ingerkedik az arra járókkal, vagyis a novella végső soron nem lép ki a fantasztikum világából. ${ }^{11}$ Bizonyos mértékig ide tartozik viszont $A$ hü szeretö (1830), A hös sirja (1834), A kecskebör (1834) valamint a befejező rész A két szomszédvárból.

Ezekben a mủvekben a képzelet az ősvilág, a tündérvilág és a történelem sokszor kozmikus távlatai helyett befelé fordul és nem kevésbé ismeretlen és fantasztikusnak látszó birodalmat teremt (vagy fedez föl): a psziché mélyvilágát. Mintha Shelley intését követné (noha más müfajban) Vörösmarty, aki szerint „A legmagasabb rendủ dráma legmagasztosabb erkölcsi célja az, hogy az emberi szívet rokonszenvei és ellenszenvei segítségével megtanítsa saját maga ismeretére"; az igazi megismerés tárgya „az emberi szív néhány legsötétebb és legtitkosabb barlangja”. ${ }^{12}$ A szív mélyének szörnyei Petőfi számára is ismerösek a Felhökben, Vörösmarty pedig drámában is felidézi őket ( a szintén az 1830-as években írott Marót bánra és Vérnászra gondolok), de a ballada és a novella nem a „szörnyek” (bosszú, féltékenység, tiltott, házasságtörő vagy vérfertőző szerelem stb.) gerjesztette tettekről szól, hanem magukat a pszichikus folyamatokat írja le. Ez különbözteti meg őket pl. a Délszigettől is, amelyről már Szerb Antal megírta, hogy a mélylélektanban ismert regresszió-jelenség kivetítéseként is olvasható ${ }^{13}$, de amely mégiscsak mitikus kalandokat, cselekményt mond el. A túlvilági képben és a Csiga Márton viszontagságaiban viszont a szó szigorú értelmében véve nem történik semmi, „csak” az álom. Turóczi-Trostler Jung említése nélkül, de a jungi kollektív emlékezet kategóriáiból kiindulva elemezte Csiga Márton álmának veszélyes lélektani jelentését: „Micsoda aljas indulatok és elfojtott ösztönök szunnyadnak a tisztességes nyárspolgár mindennapi, unalmas élete mögött, milyen jó végre egyszer túladni minden erkölcsi törvényen és gátláson! Ez a felismerés olyan megrázó, hogy a valóság el sem bírná", ${ }^{14}$ illetve irodalmi rokonságát a német romantikus novellával és a végzetdrámával is. Nem kereste viszont további esetleges rokonságát a Vörösmarty-müvek között, és értelmezését végső soron a valóság győzelmére futtatta ki, vagyis összhangba hozta az 1830-as évek uralkodó valóság-, közösség- és feladat-centrikus Vörösmarty-képével. Ugyanezt tette Szerb Antal A túlvilági képpel: „A földbe ásás képének értelme: a lélek lesüllyed az önmaga mélységeibe. Hogy a költő nem ma-

${ }^{11}$ A holdvilágos éj kitűnő és részletes elemzését adja Milbacher Róbert: „...földben állasz mély gyököddel..." Vörösmarty és Arany életmüvének pórias hagyománya címü értekezésében (Szeged 1998. Kézirat). Értelmezésében fontos szerepet játszik a novella vágyteljesítő álom-jellege.

${ }^{12}$ Előszó A Cenci-ház címü tragédiához. 1819. (magyar fordítás: Eörsi István. Magyar Helikon 1979.)

${ }^{13}$ Szerb 1971.

${ }^{14}$ Turóczi-Trostler 1961. 500. 
rad meg az önmaga mélységeiben, hanem visszatér a földi realitáshoz, hova emberi kötelessége hívja, ezt fejezi ki a költemény befejezése." 15

Véleményükkel ellentétben úgy vélem, egyik münek sem a fantasztikum elutasítása a lényege, mivel - a látszat ellenére - eleve nem uralkodó jellemzöjük „a képzelet ... korlátlan kicsapongása, "16 noha a fantasztikus müfaji eszközeit használják.

Álmokról van szó. Mennyire fantasztikusak az álmok?

Az álmok gátlásokat feloldó jelentőségét felismerve Sigmund Freud próbálta elöször tudományosan bizonyítani, hogy az álom tartalma nem egészen véletlenszerü. A müértelmezés története során magának Freudnak az öröksége is nagyon inspiratívnak bizonyult, hatása újra-újraéled és máig tart ${ }^{17}$, de egy másik ágon a Freud-tanítványként induló, majd önálló irányba térő Carl Gustav Jung munkássága is nagyon fontossá vált, különösen a kollektív emlékezet és a benne őrzött jelképek, archetípusok elmélete. A túlvilági képben a jungiánus alapú irodalmi elemzés egyik legkorábbi alaptípusa alkalmazható: az újjászületés mítosz, amely az ún. éjszakai utazás formáját ölti magára. Az ilyen típusú álmokat az átmenet és a beavatás (új életszakaszba és/vagy misztériumba) rítusaihoz kötődő archetípusok segítségével értelmezik Jung tanítványai ${ }^{18}$ Fontos része a jelképes halál, amelyből a beavatandó/álmodó más emberként tér vissza, felruházva az új életszakaszhoz szükséges tudással elsősorban önmagáról. A rítustól már eltávolodott irodalmi formákban elhalványodik a beavatás eredeti jelentése, ám megmarad a nagy megrázkódtatás és a gyökeres, az életet újraértelmező fordulat. Az éjszakai utazás irodalmi ősképe a bibliai Jónás könyve, XIX. századi példája pedig Coleridge: The Rime of the Ancient Mariner címü verse. ${ }^{19} A$ túlvilági kép címü Vörösmarty-versben az utazás mindhárom fontos elemét megtaláljuk. Az ifjú útja a föld mélyébe visz a koporsó után (vö. Jónás alászállása a mélységbe, illetve a vén tengerész kísérteties útja a halott tengeren). A föld közepében az ifjú, aki addig kedvesét vádolta hütlenséggel, egyszerre a lány gyilkosának vallja magát, vagyis fordulatot él át, felismeri és beismeri saját énjének sötét, árnyékoldalát, gyilkos féltékenységét ( mint amikor Jónás rádöbben arra, hogy hiába fut a prófétaság, a személyére szabott feladat elöl, vagy amikor a vén tengerész önkéntelenül megáldja a vízikígyókat, és ezzel mintegy el-

${ }^{15}$ Szerb 1971. 426.

${ }^{16}$ Tóth Dezső 1974. A teljes idézet: „E meglepő és kibékítő fordulat azonban mintha csak azért született volna meg, hogy elfogadhatóvá, kissé talán megbocsáthatóvá tegye a vers négyötödét kitevő víziórészt. Holott éppen ez az érték benne, ez tör új utat: a képzelet olyan korlátlan kicsapongásának ad itt Vörösmarty költői érvényt, ami már múvészi lázadásszámba megy.” (215-216.)

${ }^{17}$ Vö. pl. Jacques Derrida arche-writing vagy trace fogalmát - mindkettőnek Freud-esszé a forrása.

${ }^{18}$ Vö. pl. Marie-Louise von Franz 1993 (különösen: 179-187.), itt esik szó pl. egy olyan beavatási szertartásról, ahol a fiatalembert a sámán „egy hóba vájt gödörbe temette be. A fiatalember kimerült, álomszerü állapotba került. Ebben az ájulásszerü állapotban hirtelen egy nőt pillantott meg, akit fény ragyogott körül.” Az elemző a nőalakot a férfi animájaként értelmezi.

${ }^{19}$ Vö. a pszichoanalititikus irodalmi elemzés alapkönyve: Bodkin, Maud: 1974. (különösen a II. fejezet). 
ismeri és jóvátenni igyekszik a Természet ellen az albatrosz megölésével elkövetett bűnét). A változás előrejelzéseként jelenik meg az ifjú előtt a lány ártatlan, ragyogó alakja a „dicsőbb világ”-ban (mint a vén tengerész elött mutatkoznak meg útja vége felé a fényből szőtt égi szeráf-alakok). A felébredés/visszatérés több szinten is újjászületés: az alvilágból/a halálból térnek vissza, illetve más emberré lettek: megváltoztak.

Az ébredés tehát szükséges elem, ezért, ha így olvassuk a verset, nem fogadható el az a magyarázat, mely szerint $A$ túlvilági képben csak arra való, hogy elfogadhatóvá tegye a fantasztikus borzalmakat (Tóth Dezső), de az sem, hogy a befejezés a „veszélytelenített álom” „természetes, józan exegézise” (Turóczi-Trostler) lenne.

Vörösmarty kapcsán azonban az egyes müvek jungiánus alapú elemzésének lehetősége érdekes, de nem maga az elemzés az igazán fontos. Fontosabb, hogy segítségével belátható, hogy a költő egy pszichikai jelenséget ír le (megszabadulás egy nyomasztó traumától az álom tudatos gátlásokat oldó szerepének segítségével) - ráadásul meglepő pontossággal. Hasonlóan „reális” Csiga Márton története is: a derék átlagember lelke mélyén szunnyadó romboló ösztönök aktivizálódása, kiélése a fantasztikus álomtörténetben. Ez még belül lenne a normális pszichikai funkciók müködésén, de már a Doppelgänger, a hasonmás nemcsak a romantikus novellák kedvelt motívuma, hanem a személyiség felbomlásának, hasadásának a jele is. Klinikai tüneteit pontosan érzékeli Csiga Márton: nem látja még állandóan a hasonmást, de többször feltünik, a hős fél tőle, a hasonmás egyre gúnyosabban, ellenségesebben, agresszívan viselkedik. Csiga Márton is egyfajta belső alvilágjárást él át tehát (ha nem is a klasszikus éjszakai utazás formájában), ahonnan visszatér, de egyáltalán nem biztos, hogy a novella kedélyes-józan befejezésében jósolt társadalmi és lélektani stabilitása igazán tartós lesz. Ha egy mai pszichiáter elemezné az álmát, valószínűleg arra a következtetésre jutna, hogy a hasonmás feltünése a már megkezdődött, de még nem manifeszt kóros skizofréniás folyamat vészjelzése, figyelmeztetése, amit az öntudatlan állapot tesz lehetővé (ébren ugyanis a tudat elutasítja még a gondolatát is - vö. Csiga Márton örömét, hogy „csak tűnő álom volt").

A kecskebőr című novellában nincs álom, nincs látomás, de a hősök beszükült tudatának a babonái életre kelni látszanak képzelgéseikben. Egy ponton kapcsolódik az eddigiekhez: az elbeszélő csak utólag semlegesíti racionális magyarázattal a sajátos mekegő démóniát.

$A$ hős sírja címü versben az „ősz dalia” reménytelen öregségében már szinte csak álmaiban él: „Fáradtan, elaggva, ez álmaiban / A harc s koszorúk fia él.” „Éjfélre a hős rideg álmainál" kikapcsolódnak a tudat fékjei és az álom kísérteties hallucinációvá alakul. Az ősz daliát kürt hívja, hangja után „tévedezőn/ A képtelen éjbe halad”. Körülötte „puszta magány”, de ő harc moraját, rémületes csatadalt, kard, dárda csöngését, lovak rohanását hallja, majd „Elhallgat az éjjeli had” és a harmadik kürtszó után „villám sugarában” a saját ravatalát pillantja meg. ${ }^{20} \mathrm{Az}$ elbeszélő

${ }^{20}$ A csak hangjaival érzékeltetett csataleírást Vörösmarty néhány évvel korábban $A$ Romban már kipróbálta: a negyedik álomban az ifjú „,...nem láta, de borzasztó bús hangokat érte. /Két roppant hadnak távol hallotta csatáját, /Hallott szembe vivó sereget ordítva lehullni /S kardcsengést, megütött 
itt nem törekszik az éber és öntudatlan állapot utólagos éles szétválasztására és megmagyarázására, mint $A$ túlvilági kép és a Csiga Márton viszontagságai esetében, abban viszont hasonlóan jár el, hogy a hös tudatán belül zajló folyamatot írja le. A hallucináció tartalma itt sem véletlen: az ösz dalia egész életét a harc töltötte ki. Álma lehet akár a végső is: az utolsó versszakról nem lehet teljes bizonyossággal eldönteni, hogy része-e még a hős álmának, vagy olyan elbeszélői közlés, amely már az ösz dalia haláláról szól.

Végül A két szomszédvár utolsó jelenetére hívom fel a figyelmet. A két szomszédvár elbeszélője végig Vörösmarty epikájának legbonyolultabb narrációs technikáját müveli. ${ }^{21}$ Az Enikő halála után történteket úgy mondja el, hogy a befogadóra bízza az értelmezést: vajon Enikő kísértő alakját az eposzi machina sajátos ossziános változataként olvassa-e, vagy pedig Tihamér felbomló tudata, elhatalmasodó őrülete szimptómájaként. Az előbbi értelmezés felé billenti a mérleg nyelvét, hogy kinyílik az ajtó; az utóbbi felé, hogy Enikő első megjelenésekor Tihamér már sajátos tompaságba süllyedt: éjfélkor a várban ül egyedül és „kitekinte merően, /S gondolatok nélkül”. A második olvasat Tihamért Agnes asszony negyedszázaddal korábbi sorstársává teszi; vele is az történik, hogy Enikőt „egyre látja; Éppen úgy, mint akkor éjjel". ${ }^{22}$ Az elbeszélő itt sem foglal állást valóság és látomás dilemmájában.

A két szomszédvárral majdnem azonos időben keletkezett $A$ hü szeretö címü ballada nőalakjáról sem dönthető el, hogy kísértet vagy (titkolt lelkiismeretfurdalástól fütött) látomás. A narrátor szövegétől elválasztott, idézőjellel kiemelt megszólalások beszélőjét szinte lehetetlen azonosítani: talán maga a lány szól a huszárhoz, önmagáról egyes szám harmadik személyben beszélve. Jelenléte valósnak tünik (a huszár látja öt, szól is hozzá), egészen addig, amíg az utolsó három sorhoz nem érünk, ahol a lány (vagy az azonosíthatatlan hang) ezt mondja: „Olly vígan, o hadfia, mért rohanál? / Holt kedvesedet / Nem nézed-e meg? / Nem sír; panaszatlan a néma halál." A huszár döbben, retteg, fél, hasonlóan Tihamér rémületéhez.

Az itt bemutatott nézőpontból olvasva e műveket, nem tünik kielégítő értelmezésnek az sem, ha lényegükként az írói képzelet szélsőséges, korlátlan kicsapongását hangsúlyozzuk, és az sem, ha az álommal szemben a valóság programértékü választását emeljük ki. Hogy ez világosabban látható legyen, célszerủ a hősök és a szerző szempontjából elkülönítve vizsgálni a történetek jelentőségét. Az álmok/látomások ijesztőek és borzalmasak (még $A$ túlvilági kép hőse számára is, aki rémálma legvégén szép új világot lát, álma mégis szenvedés), nem kínálnak a hősöknek a realitással szemben választható, álomban/szerelmi halálban remélt boldogságot, mint történik például korábban $A$ hüség diadalmában, $A$ Romban, sejthető a Helvila-versekben vagy akár a Csongor és Tündében, ahol Csongor álmaiban él a

paizson nagy dárda törését /S úrtalanúl szaladó paripáknak bús dobogását, /Végre halálhörgést s zajt: többé semmit azontúl.” A hös sírjában leírt hallucináció szoros szövegbeli áthallást mutat: „S fölzengeni hallja a harc moraját,/ A férfiölő viadalt, /Küzdők rohanásit az ércsoron át, /Hall rémületes csatadalt: /Kard, dárda zörömböl, a ló szabadúl: /Nagy sebben alélva vitéz ura hull.”

${ }^{21}$ Vö. erről korábbi tanulmányomat: Az egyetlen eposz. In: Szajbély (szerk.) 1999.

${ }^{22}$ Az én kiemelésem. Z. M. 
dicső, az égi szép. Tihamér és az ősz dalia nem is tud visszatérni a józan, racionális tudat világába. A szerző felől nézve pedig sajátos kettősséget látunk: rátalált arra a sávra, ahol fantasztikum és realitás paradox módon azonossá válik. Az álmok tartalma fantasztikus, de nem véletlen: a megírt lélektani helyzetekben reális, sőt valószínü ${ }^{23}$, hogy a hősök éppen ezt álmodják, vagy ilyen látomásaik támadnak.

Ám nemcsak az irodalmi müvekben szereplő sajátos helyzetek és jelenségek lélektani alapú közelítése nyithat meg értelmezési módokat, hanem a dolog fordítva is igaz: tudjuk, hogy pl. Freud egyik híres esszéje, amely az Unheimlich (borzasztó, ijesztő, kísérteties) elemzésére vállalkozik, tulajdonképpen E. T. A Hoffmann Der Sandman (A homokember) címü elbeszélésének az elemzése. Két olvasatot is ad ró$\mathrm{la}^{24}$; számunkra most az az érdekes, hogy a történet elejét ${ }^{25}$ Freud úgy jellemzi: Nathanael leveleinek hatására bizonytalanság alakul ki az olvasóban, nem tudja, valós vagy fantasztikus világban mozog-e a történet. Ugyanezt a (lélektani) bizonytalanságot hatvan évvel később mint egy összetett beszédaktus meghatározó nyelvi elemét mutatja be Tzvetan Todorov a fantasztikusról írott tanulmányában. ${ }^{26}$ Ahhoz, hogy az általa külön müfajnak tekintett ${ }^{27}$ fantasztikus létrejöjjön, a ,bizonytalanság” modalizációja szükséges: az olvasó ne tudja eldönteni egyértelmüen, hogy szó szerinti vagy metaforikus értelemben kell olvasnia a szöveget, hogy természetes vagy természetfölötti/kívüli magyarázatot várjon stb.

Vörösmarty a romantikától máig terjedő időszak sok más írójához hasonlóan a fantasztikus elbeszélői módszereit alkalmazza a tudaton belül lejátszódó valóságos folyamatok érzékeltetésére. Többféle változatot is kipróbál. A klasszikus, Freud által is elismert bizonytalanság-fajta $A$ két szomszédvárra, $A$ hü szeretöre és $A$ hös sírjára jellemző. Vörösmarty nem használja ugyan az egyes szám első személyü elbeszélőt, ami a legtisztább megoldás lenne, mivel ilyenkor az olvasó csak az ön-elbeszélésből értesül arról, mit él át vagy vél átélni a hős (mint Hoffmann-nál Nathanael levelei, E. A. Poe The Telltale Heart címü novellájának a narrátora, vagy akár The Raven címü versének a beszélöje), mégis igen következetesen a hős saját belső nézőpontját érvényesíti. Azt olvassuk, hogy mit lát és hall Tihamér, a huszár, az ősz dalia. Az elbeszélö, akárcsak Hoffmann vagy Poe müveiben, nem

${ }^{23}$ A reális és a valószínű itt használt értelme Arisztotelész megkülönböztetésére utal a ténylegesen megtörtént és a valószinü poétikai hierarchiájáról.

${ }^{24}$ Vö. erröl Neil Hertz elemzését: Freud and the Sandman. In: Textual Strategies. Perspectives in Post-Structuralist Criticism. Ed. by Josué V. Harari. Cornell University Press, Ithaca, New York 1979.

${ }^{25}$ A bevezetésröl Ed. by Josué V. Harari. Cornell University Press, Ithaca, New York 1979.

${ }^{25}$ A bevezetésről még elismert bizonytalanság-elméletet, amelyet valószínűleg E. Jentsch cikkéből vesz, később visszautasítja a természetfölötti magyarázat kedvéért, még később viszont, némiképp önmagának is ellentmondva, a müvet a rejtett kasztrációs félelem kifejeződésének tekinti, vagyis mégiscsak két különböző szinten tartja olvashatónak, amelyek között ő maga sem dönt.

${ }^{26}$ Todorov, Tzvetan 1973., illetve Todorov 1990.

${ }^{27}$ Már a tanulmány megjelenésekor többnyire úgy látták kritikusai, hogy nem önálló múfajként, inkább hatáselemek összességeként célszerü leírni. Christine Brooke-Rose 1981. 
foglal állást, nem értelmezi, amit megírt. A hősök a kérdéses jelenetekben egyedül vannak, akár a romantikus kísértetballadák ősében, G. A. Bürger Lenoréjében a lány, vagy kései leszármazottaiban, Arany Bor vitézében ${ }^{28}$ a menyasszony vagy a Hídavatásban a játékos. Másik szereplő így nem erősítheti és nem is cáfolhatja, amit látnak-hallanak. Többek között ez a mozzanat akadályozza leginkább a bizonytalanság megszüntetését, az egyértelmüsítést bármelyik értelmezési irányban. Hamlet atyjának a szellemét ugyanis az örtálló katonák is látják, Walpole The Castle of Otranto címü regényében a lépcső tetején megjelenő gigantikus sisak az egész várnépet rémületbe ejti, Peter Schlemiltől mindenki irtózik, mert nincs árnyéka - ilyenkor a dilemma a természetfeletti javára dől el. Arany János Éjféli párbajában ellenben a menyasszony nem látja az ellenfelet, akivel Bende harcol, tehát inkább Bende örültsége a magyarázat; Goethe Erlkönigjében az apa nem látja a rémkirályt, tehát valószínübb, hogy a haldokló gyermek víziójáról van szó.

A túlvilági kép és a Csiga Márton viszontagságai annyiban tér el ettől a technikától, hogy nem annyira a bizonytalanság, inkább a meglepetés, a két világ közötti hirtelen váltás hatásmechanizmusára épít. A történetek sokáig egyértelmüen a természetfölötti szférájában olvasandónak látszanak, de a befejezésben az elbeszélö váratlanul elhatárolódik ettől az értelmezéstől, és álomnak minősíti a történteket. Itt is a hősök nézőpontja érvényesül: az elbeszélő nem ad figyelmeztető jeleket, az olvasó a hőssel egyszerre tudja csak meg a magyarázatot (A kecskebörben is hasonló történik, bár ott az olvasó az első kecskekaland után talán már kissé gyanakodva fogadja a másodikat). Bizonytalanság esetleg az elbeszélő szavahihetőségét illetően alakulhat ki: mikor higgyen neki az ember, amikor mondja, vagy amikor értelmezi a mesét?

Ilyen dilemma az 1820-as években írott Vörösmarty-müvek olvasásakor valószínüleg nem merül fel. A fantasztikum valóban alakot váltott, de szerepet, funkciót is cserélt. A változás eddig még nem tárgyalt jele a müfajváltás is.

Az előző évtized szabályos és rendhagyó eposzaiban müfaji konvenció a természetfeletti jelenléte, akár az ismert mitológiák, akár a romantikus képzelet mitológiateremtö törekvései állnak mögötte mint forrás. A olvasási szokások is így tudják: a klasszikus mintát követő és a regeszerü (a lovagi eposz és az ariostói hagyomány jegyében íródott) eposzban egyaránt betủ szerinti értelemben veendő a fa tetején ülő sárkány (Tündérvölgy), az alakváltó tündér (Zalán futása) vagy a varázssíp hangjára a földmélyi gödörből előtáncoló ördögök (Délsziget). Hasonló a helyzet a drámai költemény esetében is. Noha modern jelenség Vörösmarty korában, de müfaji mintái, a Faust vagy Byron Manfredja eget, földet, alvilágot, természetet és természetfelettit egyaránt megmozgatnak, mint Vörösmarty is a Csongor és Tündében.

Másfajta hagyományt képvisel viszont a novella és kisebb mértékben a ballada, az 1830-as évek „fantasztikus” Vörösmarty-műveinek formát adó műfajok. A novellairodalomban nemhogy nem követelmény, de még a megszokott eszköztár részének sem tekinthető a romantika előtti időkben a természetfeletti. (Hoffmann és Chamisso, Merimée és Poe újít, amikor novelláikban hangsúlyosan megjelenítik,

\footnotetext{
${ }^{28}$ Vö. erről Imre László szép elemzését: Imre 1996.
} 
kísérleteznek ijesztő, groteszk vagy nevetséges hatáslehetőségeivel.) A magyar irodalomban pedig éppen a ,való élet” megragadására különösen alkalmas formának tartották a novellát, 1830 utáni gyors és látványos térnyerésének ez az egyik fó oka. ${ }^{29}$ A ballada müfaji hagyománya annyiban különbözik a novelláétól, hogy a középkortól formálódó sokféle típusa között régóta ott van a kísértettörténet is. A magyar írói szokásokról viszont nem mondható, hogy különösebben kedvelnék: írt ilyesmit pl. Kisfaludy Károly ${ }^{30}$ és maga Vörösmarty is ${ }^{31}$, de az igazán népszerü, a kritikusok által is bátorított tematika a nemzeti történelem hőseit énekli meg.

Vörösmarty elképzelt egykori olvasójának bizonytalanság-érzéséhez tehát hozzájárulhatott az is, hogy hasonló műfajú korábbi olvasmányai nem feltétlenül segítettek eligazodni abban a kérdésben, hogy inkább „valót”, vagy inkább fantasztikumot várjon.

Nem is könnyü eldönteni. A fantasztikust új szerepe nem szembefordítja a valóval, hanem részévé teszi. Az 1830-as évek fantasztikusnak tekinthető Vörösmartyműveinek többségét megvizsgálva azt látjuk, hogy bennük az ember „,való életének" sötét, árnyékos, sokszor ijesztő oldala jelenik meg. A költő figyelme egyáltalán nem fordul el az egyéntől. Igaz, a müvek már nem azt kérdezik, mint korábban, hogy milyen életmodell, milyen értékek választása segítheti az embert a boldogsághoz. Az új kérdés a személyiség legbelső, legrejtettebb, nem ismert dimenzióira vonatkozik, a tudattalan müködéséről, ébrenlét és álom, józanság és látomás viszonyáról, sőt viszonylagosságáról szól. Kérdésesnek és kétségesnek mutatja a személyiség egységét és folytonosságát: hőseinek személyiségét vagy egymást kizáró ellentétek fenyegetik széthullással, álom-létük és éber-létük töredékes és megszakított, mintha két különböző emberről szólna (Csiga Márton, A túlvilági kép hőse, groteszk módon Röhögi és Lőcsláb is, akiket rögeszméjük forgat ki önmagukból), vagy végleg elveszítve önmaguk és a világuk fölötti kontrolljukat örületbe vagy halálba vezet az útjuk (Tihamér, az ősz dalia). Freud előtt hetven évvel a tudattalant, Lacan előtt száznegyven évvel a személyiség megosztottságát és integritáshiányát Vörösmarty a fantasztikus segítségével közelíti és jeleníti meg. Nincs még más mód, más nyelv a róla való beszédre: a lélektudomány, a pszichológia még csak a felszín feltérképezésénél tart.

Az 1830-as évek epikus és drámai müvei közvetetten inkább erősítik, mint cáfolják azt a megállapításunkat, hogy az egyén nemhogy nem szorul ki a világukból, de problémái összetettebb módon, többrétegüen jelennek meg. Határozott hangsúlyeltolódás mutatkozik a hősi-nemzeti tematikától a tipikusan magánéleti konfliktusok felé, ha az 1820-as és az 1830-as évtized balladáit, „,beszélykéit”, rövidebb elbeszélő jellegü verseit hasonlítjuk össze. Az 1830 elötti tizenegy idesorolható versből nyolc tartozik az első csoportba ${ }^{32}$, az 1830 és 1839 közötti tizenötből vi-

${ }^{29}$ Vö. erröl: Szajbély Mihály: Vélemények az 1830-as évek magyar prózájáról. In: uő. 1990.

${ }^{30} \mathrm{Pl}$. a Karácsonéj címü balladája.

${ }^{31}$ Mint korábban említettem, összesen kettőt: Az éjféli ház, Csák.

${ }^{32}$ A versek: Toldy Csepelben, Zotmund, András és Béla, Csák, Túri nöje, Szilágyi és Hajmási, A buvár Kund, Toldi, Hedvig, Laboda, Ének Hédervári Kontról (a változatokat is külön számolom). Ebből a csoportból csak a Csák, a Túri nője és a Laboda nem tekinthető nemzeti-hősi témájúnak. 
szont csak négy ${ }^{33}$, a többi szinte kivétel nélkül a szerelem, a hüség és hütlenség tragédiáiról (esetleg komédiájáról: Szép asszony, Gábor diák) szól (már Szerb Antalnak is feltünt, mennyire foglalkoztatja Vörösmartyt a hütlenség mint téma).

A drámák összehasonlításakor nem mutatkozik ilyen határozott változás, de azért a Salamon királyban vagy a Bujdosókban kialakuló konfliktus sokkal inkább nemzeti léptékü, mint a Kincskeresők (1832), a Vérnász (1833) vagy A fátyol titkai (1834). Sőt, talán még a Marót bán (1838) is jobban türi, ha a szerelmi-féltékenységi tragédiának olvassuk, mint ha történelmi tragédiának.

Ami állításunk másik súlypontját illeti - hogy ti. a pszichés folyamatok megragadására törekvő költő elsősorban azért fordul a fantasztikushoz, mert nem létezik még más mód, adekvát nyelv a közelítésre - , ez is megerősíthető analóg példával. Vörösmarty mesenovelláinak legtündériesebbike a Szél úrfi (1837). „Tündér regé”nek nevezi ő maga is, végig a fantasztikum világában játszódik. Ertékelői egyrészt a benne megnyilvánuló gazdag és játékos költői képzeletet emelik ki, másrészt azt, hogy „,betör a kispolgári ízlésbe ütköző, százszorosan tiltott, társadalmonkívüli szerelem területére". 34 De sehol sem olvastam, hogy a két megfigyelést oksági viszonyba hozták volna egymással, pedig valószínúleg van közöttük ilyen kapcsolat. A Szél úrfiban többek között prostitúcióról, majd - ami talán még botrányosabb - a prostituált társadalmi rehabilitációjáról van szó. Cselédből boldog feleség és anya lesz, olyan pozícióba kerül, ami a ,tisztességes” nők számára van fenntartva az irodalomban is. A ,bukott nő" előtt, ha megjavul is, ez az út zárva van, a társadalom törvényes reprodukciós folyamatába nem térhet vissza. Halhat önfeláldozó halált (Izidóra az Abafiban), vonulhat kolostorba (történelmi elbeszélésekben, mint pl. Minetta Kisfaludy Károly Tihamérjában), kivándorolhat a világ túlsó oldalára, de ott is csak egyedül élhet (a kis Emmy Dickens David Copperfieldjében).

Aminek a nyilvános beszédben való megjelenítéséhez még nincs hagyomány, nincs legalább valamelyest konszenzusos gyakorlat, azzal az író nehezen birkózik, vagy kerülö utat keres.

Vörösmartynál félszázaddal korábban például Barczafalvi Szabó Dávid került szembe azzal a problémával a Szigvárt fordítása közben, hogy az érzelmességnek és a nem-pátoszos szenvedélyességnek a magyar prózanyelvben semmiféle hagyománya nincs, különösen a szerelmi jeleneteket nehéz magyarra áttenni. A kérdést részletesen elemző Margócsy István szerint ez lehet talán az egyik oka Barczafalvi Szabó elképesztő szógyártásainak. ${ }^{35}$ Ugyanő idézi Dugonics Andrásnak azt a mondatát az Etelkából, amelyben ,ha nem is szándékosan, de nyíltan kimondja Barczafalvi Szabó és a szentimentális románok modernségének alapproblémáját: „Ki írhatná-le azokat az érzékenségeket, melyeknek mind-eddég neveket nem talál-

33 A versek: Szép asszony, Gábor diák, Az éjéli ház, A hü szeretö, Becskereki, Salamon, Az ösz bajnok, Szép Ilonka, A hös sirja, Kemény Simon, A rabló, A túlvilági kép, Az özvegy, Az árvizi hajós, $A$ hü lovag. Itt megfordul az arány, a nemzeti-hősi témából van kevesebb (Salamon, Az ösz bajnok, Kemény Simon, Az árvizi hajós).

34 Turóczi-Trostler (szerk.) 1948. 73.

${ }^{35}$ Margócsy István 1999, különösen 159-164. 
tunk? Nevet kellett találni az érzékenységek számára, stílust kellett kitalálni..., ${ }^{\text {„36 }}$ Neveket kell találnia Vörösmartynak is, aki a Szél úrfi írásakor halmozottan hátrányos helyzetben van: maga a téma is kétszeresen tilos ( ti. a prostitúció is, a bukott nő teljes társadalmi rehabilitációja is), és megfelelő nyelvi hagyomány sincs, amelyen írni lehetne róla. A hivatalos iratokban használt megnevezések („,feslett életü nőszemélyek”, „,kéjleányok”, „,kóbor személyek” stb. ${ }^{37}$ ) az író számára nem sok segítséget jelentenek, mivel erősen rájuk vetődik eredeti használati körük árnyéka. De ha a helyszín az elátkozott ugar, a szereplők pedig a boszorkány, a széltündér és a lánnyá változó ballangkóró, akkor a történetnek a fantasztikum menlevelet ad, még ha Gyulai szerint túlságosan ,célzatos” is a végeredmény.

Vörösmarty a nevet adni problémáját más müveiben sem Barczafalvi Szabó elszánt nekigyürkőzésével oldja meg, inkább a kikerülés különféle módozatait alkalmazza. Csák címü német költeménye végére például ,az idegen nyelv burkában és védelmében" ${ }^{38}$ ír nyersen trágár utóhangot. A Szél úrfihoz hasonló megoldás (a nemi erkölcsre vonatkozó valamilyen türéshatár feszegetése) több eposzában előfordul: férfi és (részletesen leírt) meztelen nő szerelmi jelenetében egyikük mindig tündér ${ }^{39}$ : vagyis egy másik világban, a fantasztikum világában elképzelhető és elmondható az, ami a mi világunkban nem. ${ }^{40}$

Az 1830-as években írott „,fantasztikus” Vörösmarty-müvek vizsgálata több következtetést is megenged.

A korábbi évek túláradóan gazdag képzeletvilága kétségtelenül visszaszorult, de ez összefügg a múfajváltással is. Vörösmarty nem ír több eposzt, márpedig az eposz (mindegyik variációjában) az a müfaj, amelynek konvenciói úgyszólván kötelezővé teszik a csodás, a fantasztikus jelenlétét (akad is olyan kritika, amely szóvá teszi az Eger és a Széplak ebbéli hiányosságát). A visszaszorulást talán kissé más megvilágításba helyezi, hogy az 1830-as években viszont Vörösmarty olyan müfajokban kísérletezik a fantasztikus poétikai lehetőségeivel, amelyekben egyáltalán nem lenne kötelező. Bizonyos mértékig ellene is fordul az uralkodó kritikai széljárásnak, amely a prózai müfajokban, így a novellában is a való életet kívánja feltalálni, a ballada számos változata közül pedig a hősi-történelmi témájúakat kedveli (azokkal lehet a ,hazafiérzeteket” sikeresen fölkelteni). ${ }^{41}$ Ezeknek a müveknek a fantasztikussága tehát enigmatikusabb, magyarázatot, de legalábbis találgatást kíván. Úgy tünik, az a legfontosabb változás a korábbiakhoz képest, hogy míg az

${ }^{36}$ Margócsy 1999. 162.

${ }^{37}$ Vö. dr. Siklóssy 1972. 114-115.

${ }^{38}$ Szajbély Mihály: Vörösmarty Mihály elhamvadt versei. In: uö: 1997. 22. ( Szajbély pontos fordítást közöl a versröl.)

${ }^{39}$ Vö. erről Az egyetlen eposz című tanulmányomat. In: Szajbély (szerk.) 1999.

${ }^{40}$ A XIX. századi angol irodalomban és képzőművészetben jól ismert jelenség, hogy a nyílt erotika tündérekröl és egyéb fantasztikus lényekről szóló művekben jelenik meg, így még a viktoriánus közízlés is megtüri. Vö: M. Duffy: 1972., vagy Manlove, Colin 1975. A XIX. századi magyar irodalomból is lehet más hasonló példát idézni, legjellegzetesebbek talán Tompa Mihály Virágregéi.

${ }^{41}$ Vö. a Kisfaludy Társaság 1839. februári ülésén megfogalmazott pályázati felhívás indoklása: a történeti balladák „leginkább hathatnak a nemzetre, ébresztvén és erősítvén annak hazafiérzeteit”. 
eposzokban a fantasztikus közvetlenül önmagát jelenti, addig az elbeszélésekben és a balladákban ez korántsem egyértelmű. (Hangsúlyosan figyelmeztet erre több mü elbeszélője, amikor a zárásban hirtelen váltással racionális magyarázattal látja el a történteket.) Az 1830-as évek új fantasztikuma olyan tartalmaknak ad „lakhelyet és

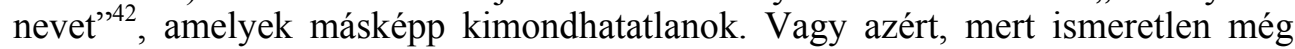
maga a tárgy - ez a helyzet a mélylélektani jelenségek között kalandozó müvekkel, mint a Csiga Márton viszontagságai, A túlvilági kép vagy $A$ hös sirja; vagy azért, mert a kor erkölcsi és irodalmi konvenciói tiltják nyilvános tárgyalását, így a róla szóló nyelv sem alakult ki (Szél úrfi). Az első változat egyben az egyén problémáinak is új irodalmi dimenziókat nyit.

Nem hiszem tehát, hogy az 1830-as évek elején érzékelhető változások után már rövidebbre fogható Vörösmarty mủvészetének az értelmezése, mivel kilép az egyéni szférából. ${ }^{43} \mathrm{Az}$ általában reprezentatívnak tekintett verscsoportban (Szózat, A hontalan, A Guttenberg-albumba, Elhagyott anya stb.) valóban kilép. Ám az évtized teljes, gazdag és változatos müfaji kínálatát figyelemmel kísérve látszik, hogy lírájában megjelennek azok a nemzeti-közösségi tartalmak, amelyeket a Vörösmarty-szakirodalom a fordulat lényegének tart, epikus müveinek tere viszont a magánélet, drámái többségének konfliktusa magántermészetü. E mủvek tanúsága szerint az emberi szenvedélyek és rögeszmék, a belölük fakadó tettek, és a mögöttük a lélek mélyén rejtőző, a tudomány számára még ismeretlen erők érdeklik Vörösmartyt. A dolgozat elején Shelleyt idéztem arról, hogy az igazi költő a szív legsötétebb barlangjait is fölkeresi; de a ma elméletének a nyelvén is megfogalmazódik ugyanez a törekvés: „Az irodalom a nyelv minden egyéb formájánál inkább a »becstelenség « diskurzusa marad: neki kell elmondania az elmondhatatlant, a legrosszabbat, a legtitkosabbat, a legtürhetetlenebbet, a szégyenletest." 44

Az elmondhatatlan elmondásával kísérletezik Vörösmarty, amikor igaz romantikus módjára szem nem látta, fül nem hallotta belső világokat fedez fel. És ha arra gondolunk, hogy a személyiség milyen torzulásait, széthullásának vagy hasadásának a fenyegetéseit látja meg, talán érthetőbb és ismerősebb lesz és nem is látszik annyira fordulatnak az, hogy az 1840-es évek közepétől emberképét a dualizmus rettenete, a sárprincípium legyőzhetetlensége ${ }^{45}$ : az őrült sár, az istenarcú lény látomása komorítja el.

\footnotetext{
${ }^{42}$ Angolul szebben hangzik. Shakespeare a Romeo és Júliában, Mercutióval mondatja a költőröl a jól ismert mondatot: ,...gives to airy nothing / a local habitation and a name”.

${ }^{43}$ Martinkó András 1977. 211.

${ }^{44}$ Foucault, Michel 1998. 105.

${ }^{45}$ Martinkó 1977. 211.
} 